IRA-International Journal of Education \&

Multidisciplinary Studies

ISSN 2455-2526; Vol.15, Issue 03 (June 2019)

Pg. no. 88-99.

Institute of Research Advances

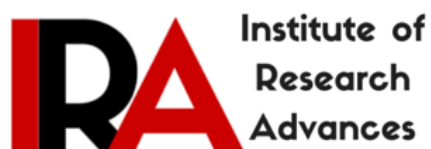

http://research-advances.org/index.php/IJEMS

\title{
A Review of the Application and Development of Output Hypothesis Theory in Foreign Language Teaching
}

\author{
Wu Yanmin ${ }^{1}$ \& Peng $\mathrm{Yi}^{2 \#}$ \\ ${ }^{1,2}$ School of Foreign Studies, Yangtze University, Hubei, 434023 P.R. China. \\ \# corresponding author \\ Type of Work: Peer Reviewed \\ DOI: http://dx.doi.org/10.21013/jems.v15.n3.p1
}

\section{How to cite this paper:}

Yanmin, W., Yi, P. (2019). A Review of the Application and Development of Output Hypothesis Theory in Foreign Language Teaching. IRA International Journal of Education and Multidisciplinary Studies (ISSN 2455-2526), 15(3), 88-99.doi: http://dx.doi.org/10.21013/jems.v15.n3.p1

(C) Institute of Research Advances.

This work is licensed under a Creative Commons Attribution-Non Commercial 4.0 International License subject to a proper citation to the publication source of the work.

Disclaimer: The scholarly papers as reviewed and published by the Institute of Research Advances (IRA) are the views and opinions of their respective authors and are not the views or opinions of the IRA. The IRA disclaims of any harm or loss caused due to the published content to any party.

Institute of Research Advances is an institutional publisher member of Publishers International Linking Association Inc. (PILA-CrossRef), USA. The institute is an institutional signatory to the Budapest Open Access Initiative, Hungary advocating the open access of scientific and scholarly knowledge. The Institute is a registered content provider under Open Access Initiative Protocol for Metadata Harvesting (OAI-PMH).

The journal is indexed \& included in WorldCat Discovery Service (USA), CrossRef Metadata Search (USA), WorldCat (USA), OCLC (USA), Open J-Gate (India), EZB (Germany) Scilit (Switzerland), Airiti (China), Bielefeld Academic Search Engine (BASE) of Bielefeld University, Germany, PKP Index of Simon Fraser University, Canada.

\footnotetext{
${ }^{1}$ Wu Yanmin is a postgraduate of QX181 in the School of Foreign Studies, Yangtze University.

2 Peng Yi (corresponding author) is an Associate Professor in the School of Foreign Studies,

Yangtze University. He is interested in language education.
} 


\section{ABSTRACT}

Since Swain proposed the theory of output hypothesis in 1985, the study focus of foreign language teaching has been shifted from input research to input and output research. The positive impact of output has been demonstrated by a large number of studies and output has been received more and more attention in the field of second language acquisition. This paper sorts out the development and application of output hypothesis theory in foreign language teaching in order to lay the foundation for further exploration.

Keywords: output hypothesis; second language acquisition; foreign language teaching

\section{Introduction}

The presentation of the output hypothesis has a specific historical background. Before combing the results of theoretical research on language output hypothesis, it is necessary to briefly introduce the theory of input hypothesis. In past foreign language teaching and research, understandable input has always been considered the most important factor in foreign language acquisition. In particular, the language input hypothesis proposed by Krashen provides theoretical support for this view(Krashen, 1982).

In the mid-1970s, the input hypothesis based on generative linguistics had an important influence on second language teaching. Krashen (1982) put forward the theory of comprehensible input " $i+1$ ". He believed that only when the learner is exposed to "understandable language input" which is slightly higher than his current language level and repeated, and he can focus on the understanding of the information and meaning rather than the understanding of the form, acquisition can be produced. " $\mathrm{i}$ " represents the current level of the learner; " $i+1$ " is the language level to be achieved by the learner in the next stage; " 1 " represents transitional distance of the learner's current language level and the language level of the learner's next stage. According to Krashen, the input is the only resource for acquiring language, and the output of language has no direct effect on learners' second language development (Krashen, 1994, 1998).

However, the defects have been exposed gradually. It does not accurately explain why the same group of students have different language acquisitions when they accept the same comprehensible input. Since the 1980s, the field of second language acquisition has begun to explore the role of output in learning. The understandable output hypothesis proposed by Swain clearly clarifies that the language output of L2 learners helps to promote to use the language fluently and accurately(Swain, 1985).

The review mainly includes three aspects. First, it is about research on the functions of the output hypothesis. Second, it introduces the applications of the output hypothesis theoretically and practically. At last, it introduces the generation, development and application of the production-oriented approach based on the output hypothesis. 


\section{The basic idea of output hypothesis}

\subsection{The appearance of output hypothesis}

According to Swain's observation and research on French-language immersion teaching in Canada at that time(Swain, 1985), she found that students' listening and reading skills are comparable to those of French native speakers by gaining a rich comprehensible input, but the language output ability, such as speaking and writing, is significantly different from that of the native language students.

Swain (1995) thought that the reason is students rarely have opportunities to practice the language based on comprehensible input. The output hypothesis claimed that the act of producing language(speaking or writing)constitutes the process of SLA under certain circumstances. Also, the processes of producing language can be quite different from the processes of comprehending language, so learners must separate from them(Swain, 2008).

\subsection{The functions of Output hypothesis}

\subsubsection{Classification}

Swain (1995) argued that the output hypothesis has four major functions for language acquisition. That is noticing function, hypothesis-testing function, metalinguistic function and fluency function.

In addition to the four functions that Swain proposed, Skehan(1998) supplemented two other functions. One is to develop discourse skills, that is, people need to express their meaning during a conversation or writing. Therefore, it is invisible to improve learner's discourse skills. The second is to develop a personal voice, that is, only when the individual has an opportunity to lead the topic to his or her interest in the conversation, and finds the way to express a method of personal opinion, and say something that you think important.

\subsubsection{The study of the language output function}

First, as for noticing function, Swain \& Lapkin (1995) conducted a study to test whether output can make them pay attention to their language problems. The result showed that learners are indeed aware of the problems in their own expressions and activate the internal cognitive processes associated with SLA. What's more, Maren(2012)showed that output influences learners' subsequent noticing of vocabulary and/or awareness of their linguistic limitations concerning grammar structures.

Second, as for hypothesis-testing function, Pica et al. (1989) found that learners partially corrected their discourse through feedback. These corrections are the process in which learners are constantly experimenting with the way of L2 expressions and verifying their own assumptions.

Third, as for metalinguistic function, Swain (1995) studied the meta-language function of the output, and the results showed that language expression and language reflection have a positive effect on the language acquisition process. Besides, Suzuki \& Itagaki(2007) attempted to investigate potential interactions among the type of meta talk, the type of task and learners' level of L2 proficiency. The reflection of the subjects showed that there is an 
interaction between the type of task and the level of the learner, in contrast, the task type determines the type and number of writing reflection of learners.

Forth, as for fluency function, Swain believed that language output can provide learners with the opportunity to use their language resources for meaningful drills, thereby enhancing the fluency of expression. Output also plays a direct role in enhancing fluency by turning declarative knowledge into procedural knowledge (Bot, 2010).

\section{The study of output hypothesis theory}

\subsection{Theoretical research}

\subsubsection{The relationship between input and output hypothesis}

Swain's output hypothesis changes people's perception of the role of language output. There is no opposite relationship between input and output and affirmation of the input does not mean the elimination of the effect of the output. In fact, all of the output exercises include language input without exception.

From the perspective of an English learner, Yu(1990) took the communication strategy problem encountered in English-speaking countries as an example and proves that only understandable input is not enough, and understandable output is essential. Meanwhile, You(2001)combined with his own college English teaching practice for many years, and he believed that second language acquisition mainly relies on a large number of input, absorption of language materials and repeated language practice by learners. He thought the key to improving English application ability is balancing the three. Furthermore, Wang(2003) explored and analyzed the reasons for the failure of college English teaching from the perspective of language input and output theory and the comparison of Chinese and Western educational models. He believed that changing traditional foreign language teaching methods, improving input quality, and making both output and input equal are the guarantees of improving teaching quality.

Therefore, we should give equal weight to both. Input can only be internalized if it is understood, and output can only be "understood" to promote language acquisition.

\subsubsection{The research of other aspects of output theory}

Zheng(2005) believed that the emergence of constructivist learning theory provides us with a new theoretical basis for understanding the role of output in second language acquisition. She discussed the positive role of output in second language acquisition from the perspective of constructivism, interaction, and practice. In addition, the discussion of teaching methods also involves the form of electrification teaching. Zeng(2005) believed that the foreign language electrification teaching based on the output hypothesis theory pays more attention to the learners' attention, and it will provide useful method guidance for constructing a new foreign language electrification education model.

Others have studied the perspective of breaking traditional linguistic research and proposed that learners should be the subject of research. Traditional linguistics only focuses 
on language forms and language structures. From the perspective of Yngve's human linguistics, Gui(2011) pointed out that the focus of output research should be from the traditional language form and language structure to how people communicate in the real world, observe and analyze people and things in a real communicative environment.

\subsubsection{Questioning the output theory and its limitations}

There are questioning voice towards the output theory. Krashen is quite controversial about the output hypothesis. He believed that the possibility of cultivating the learner's language ability through understandable language output is small or impossible, the learner's language ability may reach a higher level even without language output activities and there is some evidence that students do not like to be "pushed" to speak the target language(Krashen, 1998). Furthermore, the noticing function of the output hypothesis has been questioned. $\mathrm{Li}(2002)$ believed that the primary premise of output is that learners must have sufficient cognitive resources to complete the attention to language form and linguistic meaning because language form and meaning are competing for the limited attention of learners, noticing are an important cognitive premise for output to work and Swain has ignored it.

Concerning the limitations, first, the role of output hypothesis theory in second language acquisition is limited. Due to the complexity of internal cognition and information processing, the oral output task can only improve the attention of the target language form in a short time. How to store it in long-term memory requires further research (Gao\&Sun, 2009). What's more, Deng\&Yang(2006) argued that neither the comprehensible input hypothesis nor the comprehensible output hypothesis explains how the L2 learners acquire the target language, and it does not also fundamentally reveal the process of second language acquisition.

In foreign countries, Shehadeh (2002) believed there is still no evidence that the learner's language output and output utterance adjustment have obvious effects on language learning. Izumi and Biglow (2000) held that because most of the research is only based on assumptions, not on whether the output has an effect on language acquisition and how it works. Shehadeh believed that the reason for this phenomenon is because the current research on understandable output is mostly descriptive, the main research focus is on the learner's occurrence, nor on whether or how output become a source of second language ability development. He insisted that it is necessary to shift the focus of research from linguistic phenomena to examining the output of learners(Shehadeh, 2003).

\subsection{Teaching Practice Research}

\subsubsection{Listening and speaking}

The purpose of learning a foreign language is to communicate, so oral teaching plays a decisive role in foreign language teaching, and weak oral English is a major drawback of English teaching in China.

Guo and Qi(2009) used the empirical method to explore the feasibility of the teaching mode of "speaking and listening". After the end of the knowledge input session, the training output skills-speaking expressions activated the relevant information stored in the learner's 
mind, strengthened the clear attention to the language problems in the process of using the second language, further stimulated their cognitive mechanisms and enabled them to gradually develop the ability to use language comprehensively.

In recent years, scholars have combined the concept of spoken output and frequency to study the role of repeated spoken output. Chen et al. (2010) studied the effect of output frequency on the acquisition of English prosodic features. Besides, Zhou(2004) examined the effect of frequency on spoken output. The results showed that frequency had a certain role in promoting the content and form of oral retelling.

\subsubsection{Writing}

Writing is an important output skill, but writing teaching has always been a weak link in English teaching. How to improve students' writing ability is the focus of the attention of foreign language teachers and researchers.

"The Length Approach" is a task-based, experiential, and write-to-learn approach to foreign language learning, which mainly improves the English level of students by adjusting the length of the composition(Wang, 2005). $\mathrm{Wu}(2005)$ studied the relationship between comprehensible output and linguistic efficiency using "The Length Approach". The research results showed that the teaching mode of "the Length Approach" not only improved the learner's English writing skills but also improved the learner's English learning efficiency as a whole. Furthermore, Guo(2011) concluded that "The Length Approach" mainly reduced the students' writing anxiety and promoted students' writing ability through encouraging review, percentage system and providing a large number of language output practice opportunities through qualitative and quantitative research. In foreign countries, Alsulami(2016)examined the role and effectiveness of the noticing function of language output in developing the writing skills of the EFL, which can enable the student to identify lexis and grammar problems in his writing.

\subsubsection{Grammatical form}

A large number of empirical studies have demonstrated that output can promote grammar rule acquisition.

Feng\&Huang(2004)conducted a comparative experiment which showed two special output tasks could really promote the attention and acquisition of the language of the target language for a long time, and the effect was long-term. Besides, Wang\&Liu(2014) also conducted a group experiment which showed that when promoting the acquisition of difficult relational clauses, the output task was better than the input enhancement task. What's more, Chen(2009) used case studies to explore the role of language output in grammar acquisition and found that the output exercise itself had a limited effect on grammar acquisition, and the feedback of understanding of language problems was the key. 


\subsection{The implications of the output hypothesis for FLT}

$\mathrm{Lu}(2002)$ pointed out that in the English syllabus, teaching plan, curriculum setting and evaluation design, the concept of heavy input and light output should be changed. The output project should be fully emphasized and the teaching mode that attaches importance to output should be actively explored. Producing the target language (TL), or output, has long been considered as forming an important part of language learning. Learners have to use the language if you want to become good at it, and speak more actively in class and outside if you want to improve your English(Izumi, 2003).

Some experts also pointed out extended opportunities to produce output and receive relevant input were found to be crucial in improving the use of the target structure(Izumi\&Bigelow, 2000). Nobuyoshi\&Ellis(1993)reported a small-scale study which provided some evidence to suggest that "pushing" learners to produce more accurate output contributes to acquisition by the teacher making requests for clarification.

\section{Inheritance and development of output hypothesis theory}

\subsection{The production of POA}

In order to overcome the shortcomings of "separation of theory and practice" in FLT in Chinese universities, the production-oriented approach(POA) proposed by Wen Qiufang based on output theory came into being.

The POA has developed over more than ten years by eight English teachers from Chinese universities. The earliest version of the POA focused on an output-driven hypothesis which conjectured that output was more powerful than input in motivating university students to learn more English and perform better (Wen, 2007). Thus, Wen (2008) proposed "the output-driven hypothesis" for the teaching of English-skill courses for English majors in China. Later, Wen(2013) discussed the feasibility of using the "the output-driven hypothesis" in college English teaching, and explained from the content and rationale of the output-driven hypothesis and the implementation and the challenges of implementing the output-driven hypothesis which provided new ideas for exploring more English teaching methods in line with China's national conditions. The subsequent revised version became an output-driven input-enabled hypothesis which intended to specify the clear role of input as enabling when output served as a motivating force (Wen, 2014). Therefore, the POA as a whole was elaborated as a system.

Unlike other instructional approaches for language learning, the POA begins teaching with language production and ends with production while input serves as an enabler to help accomplish productive activities. The term "production" is different from "output", because "production" also includes interpretation and translation in addition to speaking and writing which "output" refers to. Besides, "output" emphasizes not only producing but also the product. Furthermore, the POA is mainly aimed at middle and high-level foreign language learners (Wen, 2015). 


\subsection{The development of the production-oriented approach theory}

The POA consists of three components, they are teaching principles, teaching hypotheses and teacher-mediated teaching processes. The concrete content and relations of each other will be shown in table 1 . The teaching principles set guidelines for the other two components and determine the direction and overall goal of classroom teaching. The teaching hypotheses is a theoretical basis for the teaching processes and the teaching process is a carrier that realizes the teaching principles and tests the teaching hypothesis and also a step and means to achieve POA teaching goals. At the same time, the intermediary role of teachers is reflected in all aspects of the teaching processes(Wen, 2015).

Later, Wen(2017) made three changes to the production-oriented approach theory. First, Wen added the hypothesis of "assessment-enhanced", arguing that under the guidance of teachers, students should evaluate and learn from each other, break the boundaries between "study" and "evaluation". The realization of this hypothesis is the Teacher-Student Collaborative Assessment(TSCA) (Wen, 2016). It can balance and make up for the shortcomings of the existing single evaluation methods, and at the same time, it can solve the problem that POA has many output tasks and the burden of teachers' evaluation is heavy. Second, the "teacher-mediated" in the original POA system was changed to "teacher-led". The reason is that the "intermediary role" is "imported goods", its meaning is opaque and "teacher-led" is intuitive. Third, in order to demonstrate the complexity and dynamics of teaching, the three-stage teaching process originally connected with one-way arrows was changed to a two-way arrow cycle diagram (Wen, 2017). The concrete content and relations of each other will be shown in table 2 .

In addition, Wen (2018) made some changes again. The intercultural communication competence was added in the teaching content. For the training objectives, the "key ability theory" has replaced the "whole-person education", aiming to make the educational goals more specific, more teachable and measurable. What's more, in the teaching process part, the three stages of "motivating, enabling, and assessing" were changed into internal small loops and overall big loops. At the same time, the roles of teachers and students were more clearly defined in the teaching process, and it emphasized the teaching process of teacher-student cooperation under the leadership of teachers.

Table 1 The system of the POA (Wen, 2015)

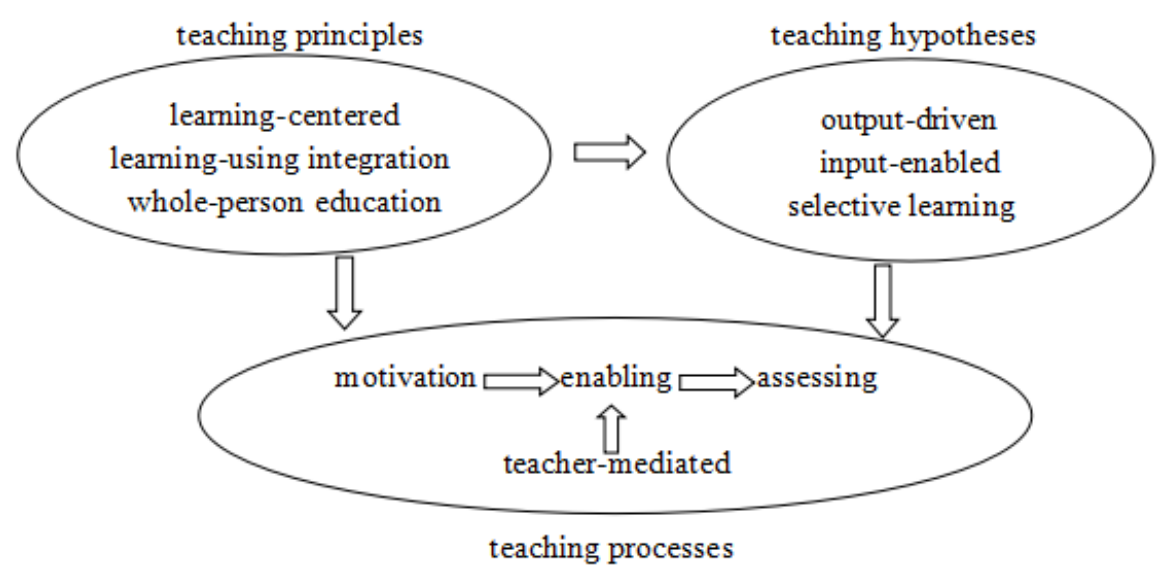


Table 2 The system of the POA (Wen, 2017)

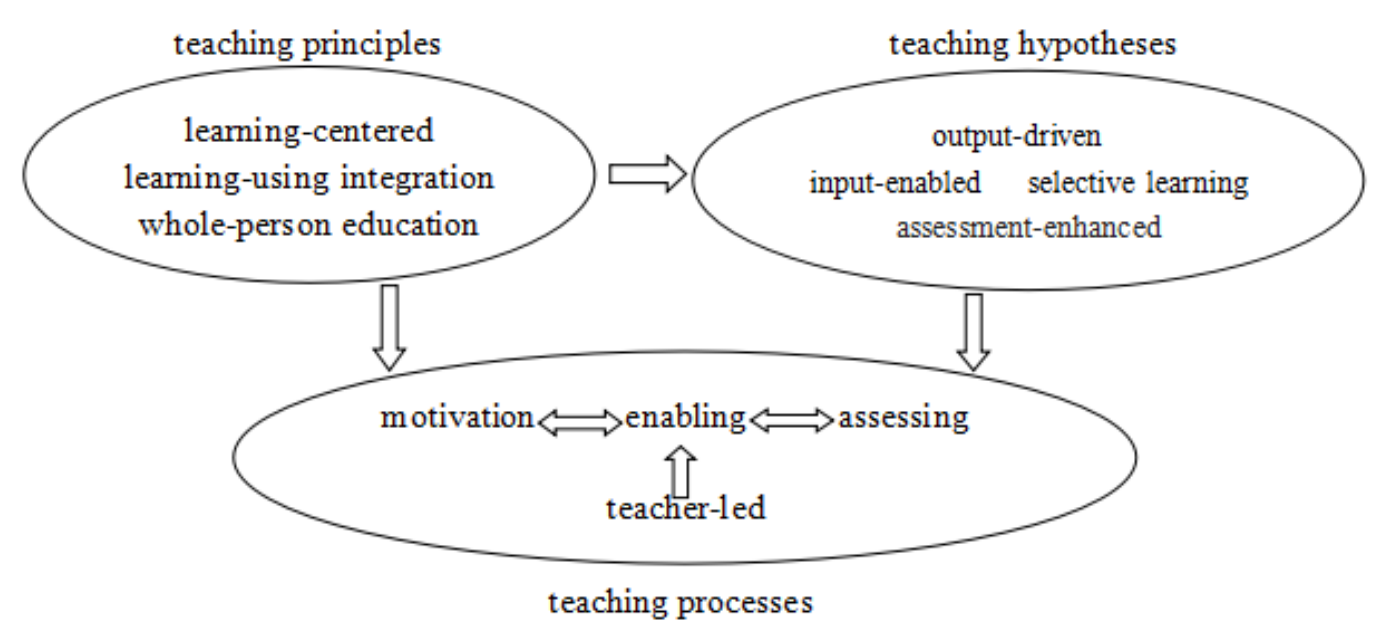

\subsection{A comparison between TBLT and POA}

Task-based Language Teaching is an important foreign language teaching concept that has emerged and formed since the 1980s. It is a task-based language teaching approach, which mainly involves organizing students to participate in meaningful communication activities during the implementation of tasks to improve language communication skills(Dong, 2015).

Compare with the two, as for pedagogical principles, they both highly pay attention to the principles of "whole person education" and "learning by doing", but they differ in the option for "learning-centeredness" or "student-centeredness". In terms of teaching hypotheses, they both emphasize the effect of input and output, but differ in"emphasizing output with less attention to input" or "input-output integrated". In teaching procedures, they both are based on language use for teaching activities but attach different importance on assessment for learning. In light of the comparison, the POA is superior to TBLT(Deng, 2018).

\subsection{The study of POA}

\subsubsection{Macro research}

By analyzing the compiling process of iEnglish based on the POA, Chang(2017) put forward a "Teaching theory-Action research" Integrated Model which explained the role of teaching theory and action research at different stages of textbook writing, and the interaction between theory and practice in this process. Finally, It proved this model can facilitate theory refinement and textbook improvement.

\subsubsection{Micro research}

Some have made some teaching practices on the POA. Zhang Lingli(2017) tested the effectiveness of the POA through a one-semester teaching experiment and pointed out the issues that need to be paid attention to and the future research direction for the effective implementation of the POA. What's more, Zhang (2016) applied this teaching theory to practice and conducted a three-week teaching experiment. She presented the teaching design 
and teaching process based on this theory and put forward some suggestions for adopting this method in EFL class. Furthermore, Zhang Wenjuan(2017)conducted a two-week experimental study to explore the effect of the POA on college students English writing quality, which revealed great superiority of the POA.

\section{Conclusion}

This paper summarizes the output hypothesis from the basic idea of the output hypothesis, the research on output hypothesis and its development. The introduction of output hypotheses has made foreign language teachers not only pay attention to the role of input but also let them notice the importance of output. A series of practices have proved the role of output in the promotion of foreign language teaching. In particular, the production-oriented approach theory proposed by Professor Wen aims to solve the problem of "separation of theory and practice" in foreign language learning in China, which has pointed out the direction for foreign language teaching. However, it is difficult to implement in China, and it needs teachers and students to make joint efforts. At present, the main objects of the output-oriented approach are college students. Whether it can be applied to primary and secondary schools is a question that needs to be considered.

\section{References}

[1]. Alsulami SQ. Testing the Noticing Function of the Output Hypothesis[J]. English Language Teaching, 2016, 9(2): 1-6.

[2]. Bot KD. The Psycholinguistics of the Output Hypothesis[J]. Language Learning, 2010, 46(3): 529-555.

[3]. Chang Xiaoling. Research on the Textbook Compilation of the Production-oriented Approach[J]. Modern Foreign Languages, 2017, 40(03): 359-368+438.

[4]. Chen Chongchong. A Case Study of the Effect of Language Output on Grammar Acquisition[J]. Journal of PLA University of Foreign Languages, 2009, 32(06): 55-59.

[5]. Chen Ye, Sun Xinping. The Effect of Input and Output Frequency on the Acquisition of English Prosodic Features[J]. Foreign Languages Research, 2010(04):1-8+112.

[6]. Deng Hailong. Comparison of the Production-oriented Approach and Task-based Language Teaching: Principles, hypothesis and Processes[J]. Foreign Language Education, 2018, 39(03):55-59.

[7]. Deng Jianlian, Yang Liexiang.Absorption Hypothesis in Second Language Acquisition[J]. Foreign Language Education, 2006(03):46-50.

[8]. Dong Fang. Construction of College Foreign Language Speaking Task-based Language Teaching Model Based on Input and Output Theory[J]. Foreign Language Research, 2015(05):123-127.

[9]. Feng Jiyuan, Huang Jiao. The Influence of Language Output Activities on Language Form Acquisition[J]. Modern Foreign Languages, 2004(02):195-200+220.

[10]. Gao Yanhong, Sun Yina. The Influence of Oral Output on the Attention of Language Forms in Second Language Learning[J]. Journal of Suzhou University (Philosophy and Social Sciences Edition), 2009, 30(03):116-118.

[11]. Gui Lin. Analysis of Output Hypothesis in Second Language Acquisition by Yngve Human Linguistics[J]. Foreign Language Research, 2011(01):99-102.

[12]. Guo Hong, Qi Deshan. An Empirical Research on Input and Output Hypothesis[J]. Foreign Language Research, 2009(01):132-135.

[13]. Guo Yan. An Experimental Study of the Influence of College English "The Length Approach" on Writing 
Anxiety and Writing Ability[J]. Foreign Language World, 2011(02):73-81+96.

[14]. Izumi S, Bigelow M. Does Output Promote Noticing and Second Language Acquisition[J]. Tesol Quarterly, 2000, 34(2): 239-278.

[15]. Izumi S. Comprehension and Production Processes in Second Language Learning: In Search of the Psycho-linguistic Rationale of the Output Hypothesis[J]. Applied Linguistics, 2003, 24(2): 168-196.

[16]. Krashen, S. Principles and Practice in Second Language Acquisition[M]. Oxford: Pergamon, 1982.

[17]. Krashen, S. The Input Hypothesis and its Rivals[A]. Implicit and Explicit Learning of Languages [C].Ed N.C.Ellis.London: Academic Press, 1994: 45-77.

[18]. Krashen, S. Comprehensible Output[J]. System , 1998(26):175-182.

[19]. Li Hong. The Cognitive Basis of Comprehensible Output Hypothesis[J]. Foreign Languages and Their Teaching, 2002(02):10-12+16.

[20]. Lu Renshun. The Enlightenment of "Output Hypothesis" Research on English Teaching in China[J]. Foreign Languages and Their Teaching, 2002(04): 34-37.

[21]. Maren S. Uggen. Reinvestigating the Noticing Function of Output[J]. Language Learning, 2012, 62(2): 506-540.

[22]. Nobuyoshi J, Ellis R. Focused Communication Tasks and Second Language Acquisition[J]. ELT Journal, 1993, 47(3): 203-210.

[23]. Pica T, Holliday L, Lewis N, et al. Comprehensive Output as an Outcome of Linguistic Demands on the Learner[J]. Studies in Second Language Acquisition, 1989, 11(1): 63-90.

[24]. Shehadeh A. Comprehensible Output, From Occurrence to Acquisition: An Agenda for Acquisitional Research[J]. Language Learning, 2002, 52(3): 597-647.

[25]. Shehadeh A. Learner Output, Hypothesis Testing, and Internalizing Linguistic Knowledge[J]. System, 2003, 31(2): 155-171.

[26]. Skehan, P. A Cognitive Approach to Language Learning[M].Oxford: Oxford University Press, 1998.

[27]. Suzuki W, Itagaki N. Learner Metalinguistic Reflections Following Output-oriented and Reflective Activities[J]. Language Awareness, 2007, 16(2): 131-146.

[28]. Swain M. Communicative Competence: Some Rules of Comprehensible Input and Comprehensible Output in its Development[A]. In S Gass \& C Madden (eds.). Input in Second Language Acquisition [C]. Rowley, MA: Newbury House, 1985. 235-253.

[29]. Swain M. Three Functions of Output in Second Language Learning [A]. In G Cook \& B Seidlhofer (eds.). Principles and Practice in Applied Linguistics: Studies in Honour of H G Widdowson[C]. Oxford: Oxford University Press, 1995, 125-144

[30]. Swain, M., \& Lapkin, S. Problems in Output and the Cognitive Processes They Generate a Step Towards Second Language Learning[J]. Applied Linguistics, 1995, 16(3): 371-391.

[31]. Swain M. Output Hypothesis: Its History and Its Future[J]. Foreign Language Teaching and Research. 2008, 40(1): 45-50.

[32]. Wang Chuming. "The Length Approach" in Foreign Language[J]. Foreign Languages in China, 2005(01): 45-49.

[33]. Wang Feng, Liu Ting. The Effect of Input Intensive Tasks and Output Tasks on the Acquisition of Clauses with Different Difficulty Relationships[J]. Foreign Language Education, 2014, 35(01):55-58.

[34]. Wang Qimin. Input and Output in College English Teaching: A Comparison of Sino Western Education Models and Its Implication to College English Teaching[J]. Foreign Language Education, 2003(03):66-69.

[35]. Wen Qiufang. Output-driven and Problem-driven Hypotheses: Reforms on the Curriculum and Teaching 
Methods for English Majors' Programs in a New Century[R]. A keynote speech at the $1^{\text {st }}$ National Forum of Chairs of English Departments, Shanghai, 2007

[36]. Wen Qiufang. The Output-driven Hypothesis and Reform of English-skill Courses for English Majors[J]. Foreign Language World, 2008(02): 2-9.

[37]. Wen Qiufang. Output-driven in-college English Teaching: Reflections and Suggestions[J]. Foreign Language World, 2013(06):14-22.

[38]. Wen Qiufang. Output-driven, Input-enabled Hypothesis: A Tentative Theory of Foreign Language Classroom Instruction for University Students[J]. Foreign Language Education in China, 2014, 7(02):3-12+98.

[39]. Wen Qiufang. Developing a Theoretical System of the Production-oriented Approach in Language Teaching[J]. Foreign Language Teaching and Research, 2015, 47(04):547-558+640.

[40]. Wen Qiufang. Teacher-Student Collaborative Assessment: An Innovative Assessment Method for the Production-oriented Approach[J]. Foreign Language World, 2016(05):37-43.

[41]. Wen Qiufang. Chinese Features Displayed in the Production-oriented Approach[J]. Modern Foreign Languages, 2017,40(03):348-358+438.

[42]. Wen Qiufang. Production-oriented Approach in Teaching Chinese as a Second Language[J]. Chinese Teaching in the World, 2018(03): 387-400.

[43]. Wu Fei. Comprehensible Output and Language Learning Efficiency: An Empirical Study of the Length[J]. Foreign Language Education, 2005(01):44-49.

[44]. You Qida. Combine Input and Output to Improve the Ability of English Application[J]. Foreign Language World, 2001(06): 40-43.

[45]. Yu L.M. The Comprehensible Output Hypothesis and Self-directed Learning: A Learner's Perspective[ J]. TESL Canada Journal,1990, 8(1): 09-26.

[46]. Zeng Wenxiong. Output Hypothesis and Media in Foreign Language Instruction[J]. Journal of Jianghan University, 2005(01):94-99.

[47]. Zhang Lingli. An Experimental Study on the Effectiveness of The Production-oriented Approach[J]. Modern Foreign Languages, 2017, 40 (03): 369-376+438.

[48]. Zhang Wenjuan. Applying Production-oriented Approach to College English Classrooms: A Teaching Experiment[J]. Foreign Languages and Their Teaching, 2016(02):106-114+147.

[49]. Zhang Wenjuan. An Experimental Study on the Effect of the Production-oriented Approach on College Students' English Writing Quality[J]. Modern Foreign Languages, 2017, 40(03):377-385+438-439.

[50]. Zheng Yinfang. The Output in SLA: A Constructive View[J]. Journal of Guangzhou University(Social Science Edition), 2005(03):93-96.

[51]. Zhou Dandan. Effects of Task Frequency on Story Retelling[J]. Journal of PLA University of Foreign Languages, 2004(05):41-45. 